\title{
OPTIMIZING RESTORATIVE JUSTICE PROGRAM FOR THE BEST INTEREST OF THE CHILDREN IN REFORMING JUVENILE JUSTICE SYSTEM IN UTAH
}

\author{
Cekli S. Pratiwi \\ Faculty of Law, University of Muhammadiyah Malang \\ International Center for Law and Religions Studies, Brigham Young University \\ J1. Raya Tlogomas No. 246, Malang, East Java, Indonesia \\ E-mail: cekli@umm.ac.id
}

\begin{abstract}
This study examine first, to what extent the fully restorative justice system could be implemented in the Utah's JJS and supported by the legislations so that the minor can enjoy a special protection while they still have the opportunity to participate actively with accountability in solving the problem without destroy their freedom and dignity and can bring more benefit to their best interest. Second, to what extent the right to legal counsel could help the minor to enjoy their constitutional rights as well as to seek a better solution of their problem. The research done by observing the review hearing, pre-trial, petition, trial at the Fourth Judicial District Courthouse Provo and the detention hearing at Slate Canyon Youth Center. The data is also collected from various secondary resources such as the Utah Statutes, the international and regional instruments. There is an opportunity for the JJS Utah county to shift from applying the partly to the fully RJP specially for truancy or misdemeanor cases and the right to access public defender should be automatically granted to the minors.
\end{abstract}

Keywords: Juvenile Restorative Justice System; The Best Interest of The Children; Juvenile Justice System

\section{A. INTRODUCTION}

Children $^{1}$ are the asset and the future of the nation. Children have significant role for the nation development. However, children are also one of vulnerable groups. ${ }^{2}$ By law, minors are vulnerable because they do not have autonomy to make decisions on their own over their own lives. Many of them are at risk of violence and become the victims of criminal actions, physical and psychological abuse, sexual harassment, family neglected, and sometimes manipulated by adults and engaged criminal actions. Therefore, the children need special

\footnotetext{
${ }^{1}$ According to Art. 1 of the $\mathrm{CRC}$, "a child means every human being below the age of eighteen years unless under the law applicable to the child, majority is attained earlier." https://www.ohchr.org/en/professionalinterest/pages/crc.aspx

2 Other vulnerable groups are women, indigenous people, minority groups, immigrant workers, refugees. See also Miller v. Alabama, No. 10-9646, 567 U.S. (2012)
} 
protection and care. ${ }^{3}$ It is the main obligation to the state, ${ }^{4}$ government, community, and parents ${ }^{5}$ to cooperate together to fully protect the children.

Children have the same human rights and fundamental freedom as adults ${ }^{6}$ that are protected by numerous international, regional human rights laws and national legislations. The United Nations framework and regional human rights treaties that give special protection to children are the Convention on the Rights of the Child (the CRC) and its optional Protocol of the Convention, the International Covenant on Civil and Political Rights/ the ICCPR (art. 10, 14, and 24), the International Covenant on Economical Social and Cultural Rights /the ICESCR (Art. 10, 12, 13), the United National Standard Minimum Rules for the Administration of Juvenile Justice (The Beijing Rules), the United Nations Standard Minimum Rules for the Treatment of Prisoners (art. 8), the American Convention on Human Rights (Art. 19), and the American Declaration of the Rights and Duties of Man (art. 7). Following the UDHR, the ICCPR, and the ICESR, every State member has the obligation to adopt the Beijing Rules when dealing with the juveniles for their best interests. ${ }^{7}$ Although the US is not a State member of the CRC that may cause children's right have not been systematically implemented, but children's rights are protected by the Fourteenth Amendments to the United State Constitution followed by the landmark Supreme Court decision recognizing their constitutional rights such as the right to access legal counsel, ${ }^{8}$ the right to access education, ${ }^{9}$ as well as the right not to be executed for criminal offense committed. ${ }^{10}$ Therefore every state, family, society has the obligation to protect every child's rights ${ }^{11}$ through special protection, care, and aid. ${ }^{12}$

Children who have the legal problem or commit the criminal acts should be handle wisely and exclusively because of their vulnerability or physically, mentally, or socially

${ }^{3}$ The United Nations Universal Declaration of Human Rights 1948 Art. 25(2).

${ }^{4}$ The CRC that has been adopted and opened for signature, ratification and accession by General Assembly resolution 44/25 of 20 November 1989 and entry into force 2 September 1990, in accordance with article 49 of the Convention. Even though the U.S.A. is not a state party of the CRC, the State could not ignore the right of the children that are protected under the CRC since the CRC has been entry into forced on 2 September 1990. The CRC has been signature by the U.S. since 1995. However, the U.S.A. is the State member of the ICCPR since 1992 and the CERD since 1994. See the Status of Ratification. Retrieved at http://indicators.ohchr.org/

${ }^{5}$ The Convention of the Rights of the Child of 1989 Article 3 (1)

${ }^{6}$ Children's Rights 2008-09-21 at the Wayback Machine, Amnesty International. Retrieved 3/29/2019

7 The United Nations General Assembly A/RES/45/122/ 68 ${ }^{\text {th }}$ plenary meeting 14 December 1990. Retrieved at http://www.un.org/documents/ga/res/45/a45r112.htm

${ }^{8}$ In re Gault (1967) regarding the right to access legal counsel. In re Gault, 387 U.S. 1 (1967).

9 Tinker v. Des Moines Independent Community School District, 393 U.S. 503 (1969)., that students in school have Constitutional rights

${ }^{10}$. Roper v. Simmons, 543. U.S. 551 (2005), that persons who below the age of eighteen may not be executed for crime committed.

${ }^{11}$ Art 19 of the American Convention on Human Rights. http://www.cidh.org/Basicos/English/Basic3.American\%20Convention.htm

${ }^{12}$ Art. 7 of the American Declaration of the Rights and Duties of Man. http://www.cidh.org/Basicos/English/Basic2.American\%20Declaration.htm 
handicapped ${ }^{13}$ and should be based on four principles that are (a) to enjoy special protection; (b) to have opportunity and facility; (c) to enable them to develop; (d) for the best interest of them. Article 5 of the CRC states:

The child shall enjoy special protection, and shall be given opportunities and facilities, by law and by other means, to enable him to develop physically, mentally, morally, spiritually and socially in a healthy and normal manner and in conditions of freedom and dignity. In the enactment of laws for this purpose, the best interests of the child shall be the paramount consideration. ${ }^{14}$

Following those principle, the CRC in 1989 on 20 November 20, Year 1989 and the United Resolution of General Assembly No. 44 emphasized that to arrest or detent children should be in conformity with the human rights law as ultimum remedium and must be finished fast within a short period of time. The treatment to the child with legal problem must be zero torture or cruel or degradation treatment as mentioned on the Convention Against Torture and Other Cruel, Inhuman or Degrading Treatment or Punishment.

Basically, in Utah, the number of children who faced legal problem have been handle through Juvenile Justice System (JJS) are declined compare to several years before, but still its conventional approach cause unnecessary suffering ${ }^{15}$ to the children and spent highly cost from the State. ${ }^{16}$ From Table 1. shows that the number of juvenile committed misdemeanor cases in District $4^{\text {th }}$ of Utah is the biggest number compare to other cases. If looking at the juvenile cases, in 2017 compare to in $2018^{17}$, the number of cases increase for 2.5 per cent, from $2,493^{18}$ cases in 2017 to 2,564 in $2018 .^{19}$. The case of felony in 2017 to 2018 also increase from 312 to 334 respectively. (See table 1). Other cases are declining. The declining of the cases number show that the JJS in Utah has been made some progresses showing from the number of the children who faced legal problem are lower than before. These development could happened because the government of Utah is willing to reform the JJS.

${ }^{13}$ The Declaration of the Child Article 3, Id.

${ }^{14}$ Article 5 of the Declaration of the Right of the Child of 19

15 Based on my observation in the Youth Center Provo, children can be brought to court and even locked up for miss behaviors that are not serious crimes, like running away or skipping school, or a child could be put back in the detention center for not obey the parent to washing dishes.

${ }^{16}$ Jessica Muler. Despite a steady decline of youths in Utah's juvenile justice system, spending has increased in recent years Updated: January 26, 2018 https://www.sltrib.com/news/2018/01/25/audit-despite-asteady-decline-of-youths-in-utahs-juvenile-justice-system-spending-has-increased-in-recent-years/

17 Utah Juvenile Courts Filings FY2017 (July 1, 2016 - June 30, 2017). Retrieved at https://ww362w.utcourts.gov/courts/juv/intro/JuvenileBro.pdf

18 Utah Juvenile Courts Filings FY2017 (July 1, 2016 - June 30, 2017). Retrieved at https://www.utcourts.gov/courts/juv/intro/JuvenileBro.pdf

${ }^{19}$ Utah Juvenile Courts Filings FY2018 (July 1, 2017 - June 30, 2018) Page 4 https://www.utcourts.gov/stats/files/2018FY/juvenile/0-Statewide.pdf 
Furthermore, the Utah Legislative audit released that JJS spending has not linier with the decreasing population in its care. ${ }^{20}$ From 2011 to 2017 , the funding was rose more than $\$ 5$ million. Auditor believe that the JJS is not aware of significant increased cost and inefficiencies in staffing and other resources are not being handled. Moreover, in term of number of recidivist still higher. The US citizens expect that the JJS create both safety for the children and for the community by considering the constitutional rights of juveniles and providing restorative justice to victims. However, the JJS are rarely implemented restorative justice system.

Table 1. The number of Juvenile Cases in District $4^{\text {th }}$ Utah from 2017 to $2018^{21}$

\begin{tabular}{|l|l|l|l|l|l|l|l|l|l|}
\hline No. & $\begin{array}{l}\text { Felo } \\
\text { ny }\end{array}$ & $\begin{array}{l}\text { Misdemea } \\
\text { nor }\end{array}$ & $\begin{array}{l}\text { conte } \\
\text { mpt }\end{array}$ & $\begin{array}{l}\text { Stat } \\
\text { us }\end{array}$ & $\begin{array}{l}\text { Adult } \\
\text { violati } \\
\text { ons }\end{array}$ & $\begin{array}{l}\text { domes } \\
\text { tic }\end{array}$ & $\begin{array}{l}\text { Child } \\
\text { welfa } \\
\text { re }\end{array}$ & $\begin{array}{l}\text { Teriminat } \\
\text { ion of } \\
\text { parental } \\
\text { right }\end{array}$ & $\begin{array}{l}\text { Voluntery } \\
\text { relinguesen } \\
\text { ment }\end{array}$ \\
\hline $\begin{array}{l}201 \\
7\end{array}$ & 312 & 2493 & 757 & 568 & 209 & 175 & 700 & 150 & 28 \\
\hline $\begin{array}{l}201 \\
8\end{array}$ & $\mathbf{3 3 4}$ & $\mathbf{2 5 6 4}$ & 115 & 376 & 293 & 164 & 680 & 245 & 41 \\
\hline
\end{tabular}

Sources: Utah Juvenile Courts Filings FY2017 and FY2018.

Although the JJS in Utah have been tried to provide a special protection for the children with the legal problems through the JJS custody programs that move the youth to less structure placements until the youth released, but the program still not enough to help the children to be able to develop in a healthy and normal manner, in condition of freedom and dignity. The research shows that the youth unnecessary separate from their parents and placed in facilities for truancy or low lower offenses or brought them before the court can actually

${ }^{20}$ Jessica Miller, January 25, 2018. Audit: Despite a steady decline of youths in Utah's juvenile justice system, spending has increased in recent years. Retrieved at https://www.sltrib.com/news/2018/01/25/auditdespite-a-steady-decline-of-youths-in-Utah's-juvenile-justice-system-spending-has-increased-in-recent-years. The author cited from the study done by Abram, K.M., Teplin, L.A., Charles, D.R., Longworth, S., McClelland, G., \& Dulcan, M. (2004). Posttraumatic stress disorder and trauma in youth in juvenile detention. Arch Gen Psychiatry, 61, 403-410, mentioned that "Studies report varying rates of Post-Traumatic Stress Disorder (PTSD) among youth in the juvenile justice system, with estimates ranging from a low of 3\% to a high of 50\%" See also Juvenile Justice Guide Book for Legislators, Mental Health Needs of Juvenile Offenders, p, 1. States that "Between 65 percent and 70 percent of the 2 million children and adolescents arrested each year in the United States have a mental health disorder." Retrieved at http://www.ncsl.org/documents/cj/jjguidebook-mental.pdf

21 Utah Juvenile Courts Filings FY2017 (July 1, 2016 - June 30, 2017). Retrieved at https://ww362w.utcourts.gov/courts/juv/intro/JuvenileBro.pdf, See also Utah Juvenile Courts Filings FY2018 (July 1, 2017 - June 30, 2018) Retrieved at https://www.utcourts.gov/stats/files/2018FY/juvenile/0-Statewide.pdf 
make their behavior much worse. Moreover, put the children in lock detention for own risk offense have higher recidivism rate than them who do not take to detention. ${ }^{22}$ The maltreatment to the children can cause traumatic, mental illness and increasing number of recidivism. Youth placed on probation or in custody spend approximately three years on average monitored by the court. ${ }^{23}$ They face excessive financial obligations that such obligations can extend length of stay, increase recidivism, and contribute to racial disparities. $^{24}$

\section{B. PROBLEM}

This study examine first, to what extent the fully restorative justice system could be implemented in the Utah's JJS and supported by the legislations so that the minor can enjoy a special protection while they still have the opportunity to participate actively with accountability in solving the problem without destroy their freedom and dignity and can bring more benefit to their best interest. Second, to what extent the right to legal counsel could help the minor to enjoy their constitutional rights as well as to seek a better solution of their problem.

\section{RESEARCH METHOD}

This study was done by attending, observing the review hearing, pre-trial, petition, trial at the Fourth Judicial District Courthouse Provo located at 37 Freedom Blvd 200 W, Provo, UT 84604 and the detention hearing at Slate Canyon Youth Center that located in $1991 \mathrm{~S}$ State St, Provo, UT 84606 for two months. Before and after the observation, the writer had the opportunity to asking some questions related to the case to the Judges of Juvenile Court namely the Honorable Judge Brent $\mathrm{H}$. Bartholomew ${ }^{25}$ in the room 3D, the Honorable Judge Suchada P. Bazzelle, ${ }^{26}$ in the room 4D and Honorable Presiding Judge F. Richards Smith III in the room 4C, public defender Mrs. Gonlazes, and Mr. Aaron Bank at DCU and the DCFS officer as well as the family members of juvenile and the juveniles and attending various guest lecturers. Beside observing in the JC, the study is done also in the detention center under supervisor a public defender, Mr. Aaron Bank. The data is also collected from various

${ }^{22}$ http://www.ncsl.org/documents/cj/jjguidebook-mental.pdf. Ibid. p. 81

23 Ibid.

${ }^{24}$ Ibid.

${ }^{25}$ Judge Brent H. Bartholomew was appointed by Governor Gary R. Herbert to the Fourth District Juvenile Court in 2013.

${ }^{26}$ Judge Suchada P. Bazzelle was appointed to the Fourth District Juvenile Court in January 2007 by Governor Jon M. Huntsman, Jr. She serves Utah and Juab counties. Judge Bazzelle graduated from the University of Colorado in 1990 with a degree in Journalism and Mass Communication and received a law degree from Brigham Young University in 1994. Id. 
secondary resources such as the Utah Statutes, the international and regional instruments related to the right of the children, journals, annual reports, or news that related with the topic that can be accessed online.

\section{RESULT AND DISCUSSION}

\section{Optimizing the Juvenile Prevention Program (JJP) through Implementing the fully Restorative Justice System}

Restorative Justice Program that has been partly implemented in Utah's JJS needs to be optimized since most number of the juvenile cases have been brought before the Juvenile Court through adjudication ${ }^{27}$ rather than non-adjudication or mediation. ${ }^{28}$ The number of children's legal problems that have been solved through the Juvenile court reach over 500,000 children per year in the United State (U.S.) ${ }^{29}$ and over 1,800 new cases per year have been filed in Utah court system. ${ }^{30}$ The JJS seems more formal, complex, and time consuming. ${ }^{31}$ The system caused negative impact towards the minor, for instant many children are suffering from mental illness or traumatic, ${ }^{32}$ stress or hopeless, even suicide. Many of the parents also reluctant to engage with the whole process of the program, ${ }^{33}$ like never show up in the court or never visiting their children during the custody ${ }^{34}$ or reject the program. The social workers

${ }^{27}$ Diversion program and work program are the example of restorative justice program that has been implemented in several places such as in Salt Lake City, Roy, and Provo and primarily serve youths from Davis, Salt Lake, Utah, and Weber Counties. Youths enrolled in diversion programs, receive daily supervision and participate in structured, constructive activities. Diversion youths also have opportunities to attend educational groups covering a variety of subjects and may take part in skill building and community service activities. However, the number of minor participation on the program is declined from year to year. Yearly average daily participation was 104.1 in FY 2014, 93.2 in FY 2015, and 64.9 in FY 2016. Meanwhile, Residential work programs help youths make amends for their delinquent behavior by giving them opportunities to work off court ordered restitution owed to their victims and service hours owed to the community. But, most children in diversion program or work program are put in the lock detention separately to their parents. The majority of youths $(59.0 \%)$ admitted to diversion programs during FY 2016 previously had been admitted to locked detention; youths (99.1\%) admitted to work programs during FY 2015 had previously been admitted to locked detention; See https://jjs.utah.gov/wp-content/uploads/2017/07/FY2016-Annual-Report.pdf

${ }^{28}$ https://jjs.utah.gov/wp-content/uploads/2017/07/FY2016-Annual-Report.pdf. Id.

${ }^{29} \mathrm{https}: / / \mathrm{www}$. utcourts.gov/specproj/casa/

${ }^{30} \mathrm{https}: / / \mathrm{www} . u t c o u r t s . g o v /$ specproj/casa/moreaboutus.asp

31 The percentage of juveniles with such disorders, among groups of delinquents that were studied, ranged from 19 percent to 67 percent (Dembo et al., 1993b, 1990b; Dembo and Associates, 1990).

${ }^{32}$ Julian D. Ford, John F. Chapman, Josephine Hawke, and David Alber. Trauma Among Youth in the Juvenile Justice System: Critical Issues and New Directions. Visit the Ncmhjj website at www.ncmhjj.com

${ }^{33}$ Based on the observation, some parents did not show up to the court during the Review Hearing because of some reason such as they need to work, they give up with the juvenile behavior, they resist with the process, or having other reasons. Based on my observation on the Youth Detention Center in Provo, a kid seems under pressure during the Detention hearing, when he said that "I don't know what will going on to me .....I feel hopeless." He falt hopeless since he had been in the Detention center for more than 30 days, the parents do not want him back to the house, and the trial was not starting yet."

${ }^{34}$ According to the observation in the Court, some parents did not show up in the court because of many reasons, first they are living far away and need to work every day, miscommunications between the parents and the 
who have been working as a front line dealing with a huge number of juvenile cases are also feel frustration, because they have big burden first to make a balance between protecting the right of the children and the right of the parent. On the other hand, they are under pressure because they need to provide strong evidence to support the public prosecutors' demands. By considering these issues, the JPP that is more informal, pro children centered approach, and quick should be developed through optimizing a fully restorative justice system in Utah.

The restorative justice system have been implemented successfully in other countries and it has been successful to decrease the number of juvenile in a whole and the number of reoffended cases. The restorative justice system is the program that can increase the responsibility of the juvenile as the offenders, the cooperative working of the parents, and the most important thing is able to restore the right of the victims. On the long term, the system becomes the effective way to reduce the risk of reoffend. ${ }^{35}$

The juvenile court has been established since 1905, while the JJP or so called Halt was established by the Netherland in $1981 .^{36}$ The Juvenile Court (JC) was established to solve the minor problem by correcting them through a formal justice system, while the Juvenile Prevention Program or so called Halt ${ }^{37}$ program is developed to prevent and combat children crime by help the children to learned their mistake through alternative informal justice system. The JJP program would be more fairness for the children rather than the JC. The JJP reduce the traumatic of the children because once the program is successfully completed by the minor, the charges are officially dismissed. Therefore the program can help the minors to avoid them from having the criminal record that could become a burden or disturb their future life.

The jurisdiction of the Juvenile Court $^{38}$ deal with the juvenile case under the age of 18 who violate a state or municipal law. The Juvenile Court also has jurisdiction in all cases involving a child who is abused, neglected or dependent. ${ }^{39}$ While the JJP or Halt program is provided for juvenile under the age of 12 to 18 to those who commit misdemeanor. ${ }^{40}$ The

children, or the parents have difficulties to find the proper time to visit. In this situation, the Prosecutor could ask the court order for a contempt of court.

${ }^{35}$ One of the objectives UTAH DIVISION OF JUVENILE JUSTICE SERVICES STRATEGIC PLAN 2018-2021 is that "JJS will accomplish the $25 \%$ success rate, defined by a reduction in risk to reoffend, by providing evidence based services with fidelity to youth in custody". See https://jjs.utah.gov/wpcontent/uploads/2018/09/JJS-Three-Year-Strategic-Plan_Final.pdf

${ }^{36} \mathrm{https} / / / \mathrm{www}$. halt.nl/en/halt-programme/background/

${ }^{37}$ Halt is a Duct organization with a national network of offices which aims to prevent and combat juvenile crime that was launched in Rotterdam in 1981. https://www.halt.nl/en/

${ }^{38}$ Historically, the Juvenile Court of Utah has been established since 1905. See Utah's Juvenile Courts, Published December 2003 by The Administrative Office of the Courts. https://www.utcourts.gov/courts/juv/intro/JuvenileBro.pdf

${ }^{39}$ Utah's Juvenile Courts, Id.

40 They are apprehended for one of the following offences:: destroying public property (Article 141(1) of the Dutch Penal Code Sr)' abuse of emergency services (Article 142(2) Sr), vandalism and graffiti (Article $350 \mathrm{Sr}$ ), (attempted) theft (e.g. shoplifting), alone or in groups (Articles 310-311 Sr), (attempted) embezzlement 
program is only provided to the offender for maximum two times. The main purpose of the Juvenile Court are:

(1) to correct the minor's problem that have failed to govern by social services or school;

(2) to protect community, orders appropriate sanctions for delinquent juveniles, and directs their rehabilitation;

(3) to deal with juvenile case such as abused, neglected, or dependent children.

The process how cases reach juvenile court are:

(1) Alleged offenses are generally first reported to the Juvenile Court by the police.

(2) At the court, cases are assigned to an intake officer who meets with both the juvenile and his or her parents to determine what action is necessary.

(a) If the juvenile denies the charge, the intake officer will set a time for a hearing with a judge.

(b) If the juvenile admits to the charge, the intake officer has two options, depending on a number of factors including the severity of the offense, the family situation, and the juvenile's age and past record.

(3) The officer may set a time for the juvenile and the parents to have a court hearing with a judge or the officer may develop a non-judicial contract that outlines how the juvenile will be held accountable for the offense that was committed.

(a) If the contract is fulfilled, the juvenile's case will not go to court.

Learning from the procedure how the court deal with juvenile case seems very formal for and take very long time. According to my observation in the Fourth District Court, the communication between Judge and other law enforcement are more informal. But, the court environment is still very formal. The judge and security are using the uniform, the court are also look very formal in which the judge sitting in his bench with higher position compare to others. These environments are believe can cause fear to the juvenile.

(Article $321 \mathrm{Sr}$, handling stolen property (Articles 416/417 Sr), switching price tags (Article $326 \mathrm{Sr}$ ), public disorderly conduct (Article $424 \mathrm{Sr}$ ), public intoxication (Article $453 \mathrm{Sr}$ ), trespass (Article $461 \mathrm{Sr}$ ), disturbing the order, peace, safety or good operation of public transport (Articles 72-73 of the Dutch Passenger Transport Act), possession of illegal fireworks, letting off legal and illegal fireworks outside the allowed times, possession of fireworks outside the period of time that fireworks may be sold, possession of more than $10 \mathrm{~kg}$ fireworks in the period of time that fireworks may be sold (Articles 1.2.2, 2.3.6, 1.2.4 of the Dutch Firework Decree), absence from school (Article 3 (3 and 4c) Leerplichtwet (Compulsory Education Act), offences in bye-laws related to fireworks or disorderly conduct. 
As we can see on table 1, the number of children who committed misdemeanor cases were very big number. It is important to provide the JJP rather than bring them to the JJS for the best interest of the children. The $\mathrm{JJP}^{41}$ is provided for the juvenile who commit minor offences. This program provides them the opportunity to learned from what they have done incorrectly. For example, once they commit the minor offence, the minor parents, the victim's parents, the minor, the representative of the minor's school, the police officer shall have a mediation, the minor voluntary tell the story, the minor have to apologies to the victims, ${ }^{42}$ do a work assignment, and pay for any damage caused, ${ }^{43}$ and promise to not repeat the mistake. If they fulfill the agreement, ${ }^{44}$ the minor will not have any criminal record. If they refuse the JJP program or they failed to fulfill the agreement, the police officer could referred the case to the public prosecutor. ${ }^{45}$

In 2017 under HB239 based on the recommendation done by the workgroup. ${ }^{46}$ This change has aims to make the low risk of minor out of JJS, to keep the moderate risk of minor in their home, school, and communities, and to help the high risk of youth placed in secure facilities because of public safety risks.

HB239 affected the Utah Juvenile Court in myriad ways.

(1) school districts are no longer able to refer low level delinquent acts, status offenses, and habitual truancy cases to the Juvenile Court. Instead, the schools are able to work with the youth through local restorative justice programs and intervention services. This way, youth with low level, school-based, and school discipline violations are not "criminalized" and pushed into the juvenile justice system. Fewer school-based referrals come to the Juvenile Court now, but serious offenses are still referred to the Juvenile Court.

(2) The Juvenile Court's nonjudicial adjustment process was expanded to include more allowable offenses and more opportunities for youth to participate, even those with repeat offenses. Again, the idea here is that youth are not pushed further into the juvenile justice system that involves more severe consequences. Instead, youth work with Juvenile Court probation officers through structured interventions, services, consequences, and restitution commitments.

${ }^{41}$ In the Netherland this program so called HALT program, in which Juveniles who commit minor offences may be referred to the HALT juvenile crime prevention programme. See https://www.government.nl/topics/sentences-and-non-punitive-orders/penalties-juvenile-offenders

42 The juvenile can express the apologies to the victims in personal with the parents accompanying or by writing a letter.

${ }^{43}$ For the juvenile at the age of 12 or 13 , who cannot be held legally responsible for the damage, will be offered assistance to reach a settlement outside the Halt program and parents will be asked to participate. Id.

${ }^{44}$ The agreement would be made in written form with the consent of their parents.

${ }^{45}$ https://www.halt.nl/en/halt-programme/contents/

46 The workgroup that consist of the members of the Juvenile Court bench and Juvenile Court administration, along with partner juvenile justice agencies have been working on six-month review of juvenile justice data and information to assist intensively and send some recommendations for legislative change. 
(3) Third, caps were placed on fines, fees, and community service hours on cases petitioned to the Juvenile Court. This way youth are not overwhelmed by commitments that in many cases they are unable to fulfill and keep them tied to the juvenile justice system.

HB239 provided a very structured decision-making process for judges to follow for high risk youth who committed serious offenses as they are considered for out-ofhome placements such as community placement and secure care.

Moreover, the HB 132 provides the opportunity to adopt the RJP at school for truancy or miss behavior. This bill is sponsored by Representative Lowry Snow during the 2017 \& 2018 of Legislative Sessions. In Section 53F-2-410 is amended to read: 36 53F-2-410. Enhancement for At-Risk Students Program.

(c) "Restorative justice program" means a school-based program or a program used or adopted by a local education agency that is designed to enhance school safety, reduce school suspensions, and limit referrals to court, and is designed to help minors take responsibility for and repair the harm of behavior that occurs in school. Lowry Snow said that putting the juvenile in the detention. ${ }^{47}$

Furthermore, in HR1 that sponsored by Representative Sandra Hollins in the 2018 Legislative $\operatorname{Session}^{48} \ldots \ldots . .$.

On the other hand, the need to increasing in the use of the NJA can help the juvenile to solve their problem quickly as the best interest for the children. NJA are voluntary agreements between youths, their parents/ guardians, and the probation department to resolve delinquency episodes referred to the Juvenile Court. These are done without the involvement of a juvenile court judge. Most youths referred for status, infraction, and misdemeanor episodes are offered non-judicial adjustments, with some exceptions for higher-risk youth and for certain serious offenses. ${ }^{49}$

It is no doubt that following the final provisions of juvenile justice reform passed by legislative on July 1, 2018, have resulted in significant changes in probation officers' work when deal with juvenile case in which the percentages of delinquency cases $^{50}$ have been resolved through non-adjudication have been significantly increase from average $22 \%$ in

\footnotetext{
${ }^{47}$ https://le.utah.gov/ 2018/bills/hbillint/HB0132S02.pdf

${ }^{48}$ House Resolution Urging Restorative Justice In Utah's Education System, 2018, General Session State Of Utah.

49 Section 78A-6-602.(2) (b) H.B. 239 Juvenile Justice Amendment 2017 General Session State of Utah. Retrieved at https://le.utah.gov/ 2017/bills/static/hb0239.html.

${ }^{50}$ The type of crime determines the severity of the referral to the Juvenile Court. There are five major severity categories for delinquency referrals: felonies, misdemeanors, contempt of court, status, and infraction.
} 
2015 to 2017 , become $55 \%$ in $2018 .^{51}$ However, this change still can be optimized more in the future for not only to the juvenile who engage in the lower-level risk delinquency case and low risk to reoffend but also to a violent or felony offense ${ }^{52}$.

By optimizing the non-adjudication adjustment, the State is able to establish a childcentered orientation system. Because in this process the juvenile and their family should have an active role and partnership within society in solving the problem. Basically, the juvenile is should not be considered as mere objects of socialization or control. The juvenile should be the subject of the system itself. Moreover, the NJA have further positive impacts because the policies promote public safety, make juveniles more responsible, ensure fairness and reduce cost. ${ }^{53}$ This principle is recognized by the United Nations Guidelines for the Prevention of Juvenile Delinquency (The Riyadh Guidelines) Adopted and proclaimed by General Assembly resolution 45/112 of 14 December $1990 .{ }^{54}$ The NJA policies are relevant for the best interest and welfare for the children as a part of their constitutional rights as well as to satisfy the fundamental rights of the parents. ${ }^{55}$

\section{The right to defender should be automatically given to juvenile on any case}

Children are human beings, they should have the same rights adult, including the right to public defender not only for the case of felony but also for the case of misdemeanor and delinquency, not only during the trial but also before and after the trial effectively. However, in juvenile case, children are less represented or not effectively represented than adult. Many children who have legal problem and put in detention for pre adjudication as well as during adjudication in the court have less access to public defender. Judges reported that most youth in the court system do not have legal representation through every stage of the court process. ${ }^{56}$

\section{According to S.B. 32 Indigent Defense Act Amendments ${ }^{57}$}

\section{1}

https://justice.utah.gov/Juvenile/HB239/Annual\%20Reports/FY_2018_HB_239_Annual_Report.html\#fn15

52 Felony level offenses, such as burglary or robbery, are the most severe. These offenses are defined as those punishable with more than one year in prison, if committed by an adult.

53 According to Section 78A-6-602. Subsection (2)(e) After July 1, 2018 “A fee, fine, or restitution included in a nonjudicial closure in accordance with Subsection 2(d) shall be based upon the ability of the minor's family to pay as determined by a statewide siding scale developed as provided in Section 63M-7$208 \ldots . .$. . These provision would help the minor's parent who are poor or having a financial problem.

${ }^{54}$ The United Nations General Assembly A/RES/45/122/ 68 ${ }^{\text {th }}$ plenary meeting 14 December 1990. Retrieved at http://www.un.org/documents/ga/res/45/a45r112.htm

${ }_{55} 62 \mathrm{~A}-4 \mathrm{a}-201$. Rights of parents -- Children's rights -- Interest and responsibility of state . Para 13721373. Retrieved at https://le.utah.gov/ 2017/bills/static/hb0239.html

${ }^{56}$ https://jjs.utah.gov/wp-content/uploads/2017/07/FY2016-Annual-Report.pdf p.81.

${ }^{57}$ Indigent Defense Act Amendments, 2019 GENERAL SESSION, STATE OF UTAH

Chief Sponsor: Todd Weiler, House Sponsor: Michael K. McKell. Retrieved at https://le.utah.gov/ 2019/bills/static/SB0032.html 


\section{A-11-201. Child welfare indigent defense services contracts -- Qualifications.(1)}

The department may enter into a contract with a qualified indigent defense service provider as defined in Section 78B-22-102 to provide indigent defense services for an indigent individual who is the subject of a petition alleging abuse, neglect, or dependency-78A-6-1111]. (2) Payment for the representation, costs, and expenses of a contracted parental defense attorney shall be made from the Child Welfare Parental Defense Fund as provided in Section 63A-11-203. (3) The parental defense attorney shall maintain the minimum qualifications as provided by this chapter.

Based on the observation, many juveniles who put in detention do not have any attorney to defend their constitutional rights. As the result, many of them are having difficulty to understand the rule. Learning from the observation in the Youth Center in Provo, public defender have only five minutes or less to talk with juvenile or give some advices, most of them do not understand about the system. Therefore during the hearing detention, every time the judge asked them questions, the answer is only short of "yes" and "no". It seems that many of juveniles do not know what was going on, what their status are, and what will be happened to them. In the case that juvenile have lack of support from their family as well as no support from public defender, they end up being hopeless or put in the detention longer.

When the process of adjudication was coming very late while the juvenile has no support from his parents or family anymore or public defender, the only thing that the minor can do is only waiting. The juvenile may feel depressed and hopeless in detention. Meanwhile, they have no legal knowledge, they also have a lack understanding about the JJS. On the other hand, if the juvenile supported by their rich parent who are able to hire private lawyer, he has opportunity to send into a home detention because the public defender help on behalf of the family to speak out their right. ${ }^{58}$ Meanwhile, for the juvenile who have full support of the family who can afford the private defender, the juvenile tends to put in the home detention.

The Statute, regulations, any other public documents related to a youth in the form of policies, brochures, legal documents, or guidelines have been found to be difficult to understand by youth, their family or parents because too complicated and use certain legal terms that are not easy to understand by society. There is also understanding that the right to have a defender is not automatically given to the juvenile. Because a juvenile delinquency proceeding is a civil action rather than a criminal proceeding. According to the Rule 26. Right of minor in delinquency proceedings states that:

Rule 26. Rights of minors in delinquency proceedings.

\footnotetext{
${ }^{58}$ Observation has been done in
} 
(a) A minor who is the subject of a delinquency petition filed pursuant to Section 78A-6-103 shall be advised of the following rights:

(a)(1) to appear in person and to defend in person or by counsel;

(a)(2) to receive a copy of the petition which contains the allegations against the minor;

(a)(3) to testify in the minor's own behalf;

(a)(4) to be confronted by the witnesses against the minor;

(a)(5) to have compulsory process to ensure the attendance of witnesses in the minor's behalf;

(a)(6) to be represented by counsel at all stages of the proceedings and if indigent, to have appointed counsel;

(a)(7) to remain silent and to be advised that anything the minor says can and will be used against the minor in any court proceedings; and

(a)(8) to appeal any adjudication against the minor in the manner provided by law.

Once the juvenile case is adjudicated, the minor will be advised their rights under the Rule 26. Both the child or the parents, guardian or custodian had been advised of the child's constitutional rights as provided in Rule 26(a) and has knowingly and voluntary waived such rights. ${ }^{59}$ This mean these rights of juvenile including the right of juvenile to have legal counsel is opened to the minor the case is filed in the court. Before the case is filed for adjudication, the right to access to legal defender is not automatically given to the juvenile. The juvenile can also waived the right if they do not want to use their rights. In this situation, the children are vulnerable not only because of their psychical, mental and social condition, but also they have lack protection under the law that block their rights to access to justice and fairness.

In 1963, in Gideon v. Wainwright, the Supreme Court affirmed the right to counsel to all criminal cases with a threat of imprisonment, both in state or federal cases and felony or

${ }^{59}$ Rule 6 Letter c(2) and c(3) of the (c)(2): "the parent, guardian or custodian had been advised of the child's constitutional rights as provided in Rule 26(a) and has knowingly and voluntarily waived such rights; and (c)(3) the child had been advised of the child's constitutional rights as provided in Rule 26(a) and has knowingly and voluntarily waived such rights." 
misdemeanor cases. ${ }^{60}$ Then, in 1967, in In re Gault the U.S. Supreme Court in In re Gault 387 U.S. 1 [1967] extended the right to counsel to juveniles in delinquency cases. ${ }^{61}$ These decision emphasized that the right to access public defender is constitutional right of the children that protected under the sixth amendment of the Constitution.

If the right to access public defender is automatically granted to juvenile then the funding for public defender would be increased to hired more number of public defender. This opportunity helps the public defender to give more time for deliver their service so that the public defender could have a chance to understand the case better, and able to find the best solution to the minor.

In Salt Lake January 29, 2019, there is a good progress when Sen. Todd Weiler, RWoods CrossIs sponsoring and calling to vote on bill requiring that children have the option of a public defender at all court proceedings. The bill have been full supported by 29 votes in every stage of legislative process without single dissenting. ${ }^{62}$ But the agreement said that they agree that the children have the access to legal counsel, but they do not agree that the state should pay for it. ${ }^{63}$ This is very important to change the law and make the right to have defender become automatically given to the juvenile whether or not they need a lawyer, someone by their side to helping and speaking up their best interests. This change may make some consequences for the State to add the budget for public defender and to add the number of public defender since the case of juvenile in Utah is quite big number.

The presence of public defender who has a better understanding about the JJS could help the juvenile prior or during the adjudication process. The opportunity to have a public defender very early will help them to optimize the non-adjudication system to be used. Because, the non-judicial agreement seems not optimal to be used since the number of agreement between family and children or family and victims are not much or they failed to make some agreement in which petition will be continued.

\section{E. CONCLUSION}

\section{Juveniles.pdf}

60 (Feld and Schaefer, 2010). See https://www.ojjdp.gov/mpg/litreviews/Indigent-Defense-for-

${ }^{61}$ In re Gault case first brought the issue of juvenile indigent defense to the public's attention. Gerald Gault, 15, of Arizona was accused of making an crank phone call to his neighbor, 15 years old friend. Then, he caught by the police without the concern of their parents and without any receive any legal counsel, he was arrested and later sentenced to 6 years in confinement until he is turned 21 years old. If was an adult, he could be fine for only $\$ 50$ and two months in a jail. In re Gault 387 U.S. 1 [1967].

${ }^{62}$ https://le.utah.gov/av/floorArchive.jsp?markerID=105765

${ }^{63}$ Benjamin Fodd. Full Utah House to vote on bill requiring that children have the option of a public defender. February 22, 2019. at all court proceedingshttps://www.sltrib.com/news/politics/2019/02/22/full-utahhouse-vote-bill/ 
There is no doubt that children's right are well protected by international, regional human rights law as well as the Utah State and Federal Constitution of the U.S. However, to ensure that all children's rights are effectively protected by the all states, it is very urgent for the U.S. to ratified the CRC. By understanding the vulnerability of the children can create the new paradigm for law enforcements, community, and parents that children need to be protected in special way and not to be separated to their families so that they can participate actively to understand their mistake, take responsibility of their wrongdoer without any fear or destroy their future life and restore the right of the victims. There is a big opportunity for the JJS Utah county to shift from applying the partly to the fully RJP specially for truancy or misdemeanor cases since there are some Bills that have been proved to support the programs namely HB 239, HB 132 and HR1. In order to support the implementation of the program, many of law students from the law school in Utah County can be selected and trained to be technical assistants by Utah Juvenile Working Groups. In order to optimize the implementation of the RJP and all facilities that more pro to the right of the children, the right to access public defender should be automatically granted to the minors.

\section{ACKNWOLEDGMENT}

I thank you to Professor Carl Hernandez who supervised the author on doing the observation at Youth Correction Center and in Juvenile Court in Utah and Judge Farah who always went together to do this activities. I also thank you to the Judges of Juvenile Court namely the Honorable Judge Brent H. Bartholomew, the Honorable Judge Suchada P. Bazzelle, Honorable Presiding Judge F. Richards Smith III, public defender Mrs. Gonlazes, and Mr. Aaron Bank at DCU and the DCFS officer as well as the family members of juvenile and the juveniles and attending various guest lecturers, and a public defender, Mr. Aaron Bank who always available for having deeply discussion in some relevant issues

\section{REFERENCES}

Abram, K.M., Teplin, L.A., Charles, D.R., Longworth, S., McClelland, G., \& Dulcan, M. Posttraumatic stress disorder and trauma in youth in juvenile detention. Arch Gen Psychiatry. 2004.

Benjamin Fodd. Full Utah House to vote on bill requiring that children have the option of a public defender. February 22, 2019. at all court proceedingshttps://www.sltrib.com/news/politics/2019/02/22/full-utah-house-votebill/

Children's Rights 2008-09-21 at the Wayback Machine, Amnesty International. Retrieved $3 / 29 / 2019$ 
Dembo et al., 1993b, 1990b; Dembo and Associates, 1990.

Feld and Schaefer, 2010. See https://www.ojjdp.gov/mpg/litreviews/Indigent-Defense-forJuveniles.pdf

House Resolution Urging Restorative Justice In Utah's Education System, General Session State Of Utah. 2018.

https://justice.utah.gov/Juvenile/HB239/Annual\%20Reports/FY_2018_HB_239_Annual_Rep ort.html\#fn15

https://le.utah.gov/ 2018/bills/hbillint/HB0132S02.pdf

https://www.halt.nl/en/halt-programme/background/

In re Gault, Regarding The Right to Access Legal Counsel. 387 U.S. 1. 1967.

Indigent Defense Act Amendments, 2019 GENERAL SESSION, STATE OF UTAH Chief Sponsor: Todd Weiler, House Sponsor: Michael K. McKell. Retrieved at https://le.utah.gov/ 2019/bills/static/SB0032.html

Jessica Muler. Despite A Steady Decline Of Youths In Utah's Juvenile Justice System, Spending Has Increased In Recent Years Updated: January 26, 2018 https://www.sltrib.com/news/2018/01/25/audit-despite-a-steady-decline-of-youths-inutahs-juvenile-justice-system-spending-has-increased-in-recent-years/

Julian D. Ford, John F. Chapman, Josephine Hawke, and David Alber. Trauma Among Youth in the Juvenile Justice System: Critical Issues and New Directions. Visit the Ncmhjj website at www.ncmhjj.com

Juvenile Justice Amendment 2017 General Session State of Utah. Retrieved at https://le.utah.gov/ 2017/bills/static/hb0239.html.

Juvenile Justice Guide Book for Legislators, Mental Health Needs of Juvenile Offenders, Retrieved at http://www.ncsl.org/documents/cj/jjguidebook-mental.pdf

The American Convention Human Rights. http://www.cidh.org/Basicos/English/Basic3.American\%20Convention.htm

The American Declaration of the Rights and Duties of Man. http://www.cidh.org/Basicos/English/Basic2.American\%20Declaration.htm

The Convention of the Rights of the Child of 1989.

The Declaration of the Child.

The United Nations General Assembly A/RES/45/122/ $68^{\text {th }}$ plenary meeting 14 December 1990. Retrieved at http://www.un.org/documents/ga/res/45/a45r112.htm 
Tinker v. Des Moines Independent Community School District, 393 U.S. 503. 1969.

United Nations Universal Declaration of Human Rights 1948

Utah Division of Juvenile Justice Services Strategic Plan 2018-2021 See https://jjs.utah.gov/wp-content/uploads/2018/09/JJS-Three-Year-StrategicPlan_Final.pdf

Utah Juvenile Courts Filings FY2017 (July 1, 2016 -June 30, 2017). Retrieved at https://ww362w.utcourts.gov/courts/juv/intro/JuvenileBro.pdf

Utah Juvenile Courts Filings FY2018 (July 1, 2017 -June 30, 2018) Page 4 https://www.utcourts.gov/stats/files/2018FY/juvenile/0-Statewide.pdf

Utah Juvenile Courts, Published December 2003 by The Administrative Office of the Courts. https://www.utcourts.gov/courts/juv/intro/JuvenileBro.pdf 